\title{
ANALISIS MANFAAT PENYERTAAN MODAL NEGARA PADA PROGRAM PEMBANGUNAN INFRASTRUKTUR LISTRIK DESA PROVINSI BALI
}

\author{
Muhammad Heru Akhmadi', Putu Nanda Priastawan ${ }^{2}$ \\ 1,2Politeknik Keuangan Negara STAN Indonesia
}

\begin{abstract}
Electricity infrastructure needs to be developed following economic growth. Fulfilling electricity infrastructure in Indonesia, the government targets an increase in the electrification ratio of 100 percent through the village electricity infrastructure development program. To achieve this, the government invests through State Equity Participation in PT. PLN as a State-Owned Enterprise that manages state electricity. This study aims to see how the implementation of government investment through PMN in the village electricity infrastructure program in Bali Province for the period 20132020. This study also wants to see how the benefits generated from government investment. This study uses a qualitative method using Atlas.ti software to analyze the results of interviews by providing the most relevant codes to answer research questions. The results show that the village electricity infrastructure program in Bali Province has encouraged the achievement of an electrification ratio of $100 \%$. Other results show that government investment generated economic and social benefits. The economic benefits such as got dividends as state revenue and reduced household operating costs. The social benefits such as improved the quality of life, increased productivity, added insight and information, and facilitated the growth of small and medium enterprises in the province of Bali.
\end{abstract}

Keywords: public investment; village electricity; infrastructure; project benefit; public finance

\begin{abstract}
ABSTRAK
Infrastruktur tenaga listrik perlu dikembangkan mengikuti pertumbuhan ekonomi. Untuk memenuhi infrastruktur kelistrikan di Indonesia, pemerintah menargetkan peningkatan rasio elektrifikasi sebesar 100 persen melalui program pembangunan infrastruktur kelistrikan desa. Untuk mencapai hal tersebut, pemerintah melakukan investasi melalui Penyertaan Modal Negara pada PT. PLN sebagai Badan Usaha Milik Negara yang mengelola kelistrikan negara. Penelitian ini bertujuan untuk melihat bagaimana implementasi investasi pemerintah melalui PMN pada program infrastruktur kelistrikan desa di Provinsi Bali periode 2013-2020. Penelitian ini juga ingin melihat bagaimana manfaat yang dihasilkan dari investasi pemerintah. Penelitian ini menggunakan metode kualitatif dengan menggunakan software Atlas.ti untuk menganalisis hasil wawancara dengan memberikan kode-kode yang paling relevan untuk menjawab pertanyaan penelitian. Hasil penelitian menunjukkan bahwa program infrastruktur kelistrikan desa di Provinsi Bali telah mendorong tercapainya rasio elektrifikasi sebesar 100\%. Hasil lain menunjukkan bahwa investasi pemerintah menghasilkan manfaat ekonomi dan sosial. Manfaat ekonomi seperti mendapat dividen sebagai penerimaan negara dan mengurangi biaya operasional rumah tangga. Manfaat sosial seperti peningkatan kualitas hidup, peningkatan produktivitas, penambahan wawasan dan informasi, serta memperlancar pertumbuhan usaha kecil dan menengah di Provinsi Bali.
\end{abstract}

Kata kunci: investasi publik; listrik desa; infrastruktur; manfaat proyek; keuangan publik 


\section{PENDAHULUAN}

Penyediaan infrastruktur berpengaruh positif terhadap pertumbuhan ekonomi wilayah dan menurunkan kemiskinan (Sumardjoko, 2019). Kebutuhan energi, khususnya energi listrik, semakin berkembang menjadi bagian yang tak terpisahkan dari kebutuhan hidup masyarakat sehari-hari di berbagai belahan dunia seiring dengan pesatnya peningkatan pembangunan di bidang industri, informasi, dan teknologi. Ketersediaan pasokan listrik di Indonesia dikuasausahakan kepada PT PLN berdasarkan Peraturan Pemerintah Nomor 17 Tahun 1990.

Sektor kelistrikan digolongkan sebagai infrastruktur dasar sangat berpengaruh terhadap perkembangan investasi di Indonesia (Riastuti, 2008). Aktivitas sehari-hari masyarakat yang memerlukan listrik non-stop 24 jam dalam seminggu, mengharuskan PLN Distribusi dan Transmisi selalu memastikan ketersediaan pasokan listrik dengan cara antisipasi kerusakan dan kapasitas listrik, khususnya di tiap-tiap daerah. Kapasitas listrik yang kurang dapat dipenuhi dengan penambahan transmisi.

Pelaksanaan Pembangunan pada sektor tenaga listrik ini mulanya digagas pemerintah untuk mendorong kegiatan ekonomi yang juga berujung pada kesejahteraan masyarakat sekaligus memacu kecerdasan masyarakat khususnya di daerah pedesaan. Program listrik desa mulanya di gagas dalam uraian Hartono Kadri (1960) dimana didalamnya dinyatakan bahwa tujuan dari program Listrik Desa ini adalah "pemberian dan pemakaian listrik di desa-desa untuk meninggikan produktivitas desa-desa dalam lapangan pertanian maupun industri kerajinan rakyat".

Dalam memenuhi kebutuhan tersebut PT. Perusahaan Listrik Negara (PLN) melaksanakan pengembangan saluran transmisi dan Gardu Induk (GI) yang diarahkan kepada keseimbangan antara kapasitas pembangkitan di sisi hulu dan permintaan daya di sisi hilir secara efisien dengan memenuhi kriteria keandalan tertentu. PT PLN kerap kali melakukan power wheeling. Power wheeling ini bertujuan agar aset jaringan transmisi dan distribusi sebagai salah satu aset bangsa dapat dimanfaatkan dengan optimal sehingga mempercepat peningkatan kapasitas pembangkit nasional untuk menunjang pertumbuhan ekonomi nasional.

Pada pembangunan transmisi dan GI area Jawa - Bali dibangun Transmisi dan GI 500 KV (Kilo Volt) pada periode 2015-2024, PT.PLN mendapatkan pembiayaan melalui Penyertaan Modal Negara (PMN) kepada BUMN) kepada PLN sebanyak Rp40,06 Triliun selama tahun 2015-2020. Proyek pembangunan ini tak jarang mendapat kritikan dari berbagai pihak yang menilai kebijakan PLN tidak efektif, khususnya dalam mengelola dana pemerintah. Hal ini disebabkan karena kebijakan dan pembangunan PLN yang dananya bersumber dari PMN tersebut tidak dapat dirasakan manfaatnya oleh beberapa pihak.

Berkaitan dengan hal tersebut, penelitian ini akan menelaah pelaksanaan dan manfaat dari investasi pemerintah melalui PMN dengan kasus pada program pembangunan listrik desa yang dilaksanakan di provinsi Bali. Secara detail terdapat dua permasalahan yang akan dibahas, yaitu bagaimana pelaksanaan Investasi Pemerintah melalui PMN pada pembangunan listrik desa di Provinsi Bali dan bagaimana manfaat Investasi Pemerintah yang dihasilkan sehubungan pembangunan listrik desa di Provinsi Bali.

Hasil penelitian ini diharapkan dapat memberikan pengetahuan kepada masyarakat dan 
pengambil kebijakan terkait efektifitas implementasi proyek pembangunan transmisi dan GI area Jawa-Bali serta manfaat yang dihasilkan dari pembangunan tersebut secara ekonomi dan sosial bagi masyarakat dan daerah. Pada penelitian ini beberapa variabel yang dibahas antara lain : Penyertaan Modal Negara, Biaya dan Manfaat, dan Rasio elektrifikasi.

\subsection{Penyertaan Modal Negara}

Berdasarkan Peraturan Pemerintah Republik Indonesia Nomor 44 Tahun 2005, Penyertaan Modal Negara (PMN) merupakan proses pemisahan kekayaan negara dari Anggaran Pendapatan dan Belanja Negara atau penetapan cadangan perusahaan atau sumber lain untuk dijadikan sebagai modal BUMN dan/atau Perseroan Terbatas lainnya, dan dikelola secara korporasi. Selanjutnya Peraturan Pemerintah Nomor 72 Tahun 2016 tentang Perubahan atas Peraturan Pemerintah Nomor 44 Tahun 2005 tentang Tata Cara Penyertaan dan Penatausahaan Modal Negara pada badan Usaha Milik Negara dan Perseroan terbatas menjelaskan sumber Penyertaan Modal Negara yaitu dari : APBN, Kapitalisasi Cadangan, dan/atau Sumber lainnya.

Penyaluran PMN dapat dilakukan dalam berbagai bentuk, seperti aset, tunai, ataupun hak negara yang dapat dinilai dengan uang. Beberapa tahun terakhir, pemerintah memberikan PMN dalam jumlah besar ini yang menunjukkan komitmen pemerintah dalam meningkatkan investasi pemerintah dalam mencapai beberapa proyek strategis nasional. PMN juga dapat memberikan efek pengganda atau multiplier effect dalam perekonomian. Dalam hal ini BUMN diharapkan mampu memaksimalkan perannya sebagai 'agent of development' yang berperan aktif dalam mendukung program nasional.

Selanjutnya pemberian PMN kepada BUMN umumnya dilakukan dalam rangka meningkatkan kapasitas usaha pada BUMN tersebut dan juga membantu memperbaiki struktur permodalan BUMN. Penyertaan Modal Negara ini diharapkan dapat meningkatkan kontribusi BUMN dalam mendukung program Nawacita yang merupakan program prioritas nasional, antara lain seperti mendukung kedaulatan pangan, pembangunan maritim, infrastruktur, industri , konduktivitas, pertahanan dan keamanan, dan juga kemandirian ekonomi nasional.

Alur mekanisme penyaluran PMN berdasarkan Peraturan Pemerintah Nomor 4 Tahun 2005 Tentang Tata Cara-Penyertaan Dan Penatausahaan Modal Negara-BUMN sebagai berikut:

1. Penyertaan Modal Negara atau PMN mulanya diusulkan oleh Menteri Keuangan kepada Presiden disertai dasar pertimbangan pemberian PMN tersebut setelah dikaji bersama dengan Menteri dan Menteri Teknis.

2. Rencana PMN dapat dilakukan berdasarkan inisiatif Menteri keuangan, Menteri, dan/atau Menteri Teknis.

3. Pengkajian bersama antara Menteri Keuangan, Menteri, dan Menteri Teknis, dikoordinasikan oleh Menteri Keuangan.

4. Pengkajian dapat juga mengikutsertakan menteri lain ataupun pimpinan instansi lain yang dianggap perlu atau bisa juga menggunakan konsultan independen.

Terdapat banyak pihak yang terlibat dalam mekanisme Penyertaan modal negara dari perencanaan hingga PMN dapat diterima oleh BUMN (Bakroh, 2020). Pihak-pihak tersebut antara lain :

a. Pada tahap perencanaan PMN, Direktorat Jenderal Kekayaan Negara (DJKN) mengkaji usulan PMN, melakukan pembahasan dengan BUMN atas usulan PMN, menyampaikan kajian kepada Menteri Keuangan, mengusulkan kepada DJA untuk mengalokasikan PMN, 
melakukan pembahasan dengan DPR RI. Kemudian BUMN melakukan pembahasan dengan DJKN atas usulan PMN yang diajukan.

b. Pada tahap pelaksanaan PMN, DJKN: menerbitkan DIPA, SPM/SP2D, mencairkan anggaran ke rekening perusahaan, dan menyusun laporan pertanggungjawaban. Berperan sebagai RUPS, memberikan arahan atau policy bagi perusahaan, memberikan guideline bagi BUMN atau lembaga, pengawasan, dan membangun Good Corporate Governance. Pun dalam proses yang dilaksanakan DJKN berperan aktif dalam melakukan kajian, memberi persetujuan, dan melakukan pengawasan.

c. Pada tahap pelaporan, BUMN membuat laporan investasi pemerintah berupa PMN yang diterimanya pada tahun berjalan, dan kemudian disetorkan ke DJKN. Selanjutnya DJKN sebagai datacenter investasi pemerintah menatausahakan dan melaporkan apa yang diterima dari BUMN melalui SAIP, menyusun laporan Investasi Pemerintah untuk kemudian diapresiasi oleh BPK untuk mendapatkan opini.

\subsection{Manfaat Investasi Pemerintah}

Pengukuran manfaat Investasi Pemerintah melalui Penyertaan Modal Negara pada PT PLN bertujuan untuk mengetahui apakah suatu proyek yang didanai melalui PMN tersebut mampu memberikan manfaat bagi organisasi, pemerintah, dan masyarakat entah itu manfaat yang bersifat tangible maupun intangible dengan biaya yang sudah dikeluarkan oleh organisasi (Yulia, 2005).

Manfaat Berwujud atau Tangible Benefit merupakan Manfaat Berwujud dari investasi pemerintah yang diperoleh melalui penghematan biaya akibat adanya investasi tersebut. Analisis manfaat berwujud dilakukan dengan empat metode pendekatan, yaitu cost displacement, cost avoidance, decision analysis dan impact analysis. Terdapat beberapa metode yang bisa digunakan dalam melakukan pengukuran kelayakan investasi, diantaranya cost and benefit analysis (Miswanto et al, 2020). Pendekatan Metode Cost and Benefit analysis hanya dapat mengukur manfaat ekonomi ataupun finansial dari sebuah investasi. Terkait investasi pemerintah tak hanya berbicara soal manfaat ekonomi, namun juga manfaat sosial. Manfaat sosial dapat diukur dengan metode Kajian ekonometrika yang membahas pengukuran hubungan ekonomi, teori ekonomi, matematika, dan statistika dalam satu kesatuan sistem yang berdiri sendiri dengan kuat. Ekonometrika sendiri digunakan untuk analisis ekonomi terhadap variabel ekonomi dan data empiris (Aziz, 2007).

Metode Cost And Benefit Analysis atau CBA yang digunakan dalam pengukuran ini adalah analisis yang dilakukan dengan membandingkan antara biaya yang dikeluarkan oleh pemerintah (cost) dengan benefit atau keuntungan dan manfaat yang diterima / yang didapat oleh pihak terkait, diantaranya PT PLN, Pemerintah, dan Masyarakat (Sulistiani, Miswanto, \& Damayanti, 2020). Biaya merupakan unsur berupa nilai komponen yang dikeluarkan untuk memenuhi satu program atau tujuan tertentu dalam melakukan Penyertaan Modal Negara, sedangkan unsur benefit atau manfaat adalah unsur positif ataupun negatif daripada program PMN yang dirasakan pihak terkait. Cost And Benefit dalam hal ini mencakup tangible dan intangible (Ekawati, 2016)

Sebelum pengukuran nilai biaya dan manfaat dari PMN pada program Transmisi dan GI PT PLN Jawa-Bali, perlu dilakukan identifikasi terlebih dahulu terkait biaya-biaya yang digunakan dalam pembangunan yang dananya bersumber dari Penyertaan Modal Negara ini. Identifikasi unsur biaya dan manfaat tersebut sebagai berikut : 
(1.) Start up cost: adalah biaya yang dikeluarkan untuk mendukung kebutuhan operasional. Start up cost biasanya dikeluarkan pada awal" berlangsungnya proyek.

(2.) Procurement Cost: adalah total cost atau biaya keseluruhan dalam pengadaan perangkat keras yang diperlukan dalam proyek pembangunan yang berasal dari PMN ini, yaitu pembangunan listrik desa. Misalnya dalam pengadaan tiang listrik, kabel, dan perangkat keras lainnya.

(3.) Project Cost: adalah biaya yang biasanya muncul di tengah berkembangnya satu proyek dan dapat dikatakan sebagai pengeluaran ketika proyek itu sudah mulai berjalan.

\subsection{Rasio Elektrifikasi}

Berdasarkan Peraturan Pemerintah Republik Indonesia Nomor 79 Tahun 2014 Tentang kebijakan Energi Nasional, Rasio elektrifikasi merupakan Perbandingan antara Banyaknya rumah tangga yang telah berlistrik dengan total rumah tangga di satu wilayah tersebut. Pada dasarnya, pelanggan PT PLN dibedakan ke dalam beberapa kelompok yaitu R(rumah tangga), P (Publik), B (Bisnis), S(Sosial), I (Industri), dan L (Sementara). Sedangkan selama ini (Sebelum tahun 2018) PT PLN Melakukan Pengukuran Rasio Elektrifikasi hanya terhadap rumah tangga yang memiliki identitas tarif $\mathrm{R}$, sehingga kurang akurat.

Rumus Rasio Elektrifikasi adalah sebagai berikut:

$$
\text { jumlah Rumah tangga RPBSIL yang sudah mendapat listrik }
$$

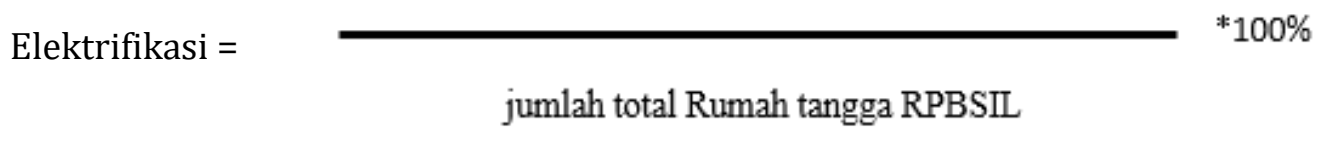

Dengan adanya rasio elektrifikasi, dapat memudahkan dalam memantau perkembangan jaringan listrik di Indonesia, menjadi tolak ukur dalam mengajukan Penyertaan Modal Negara kepada Pemerintah Pusat, dan juga tentunya dapat dengan segera meningkatkan taraf hidup masyarakat sesuai dengan Program Pemerintah Pusat sehingga tidak ada lagi desa yang tertinggal tidak mendapat fasilitas listrik (Afifi \& Sastry, 2013).

\section{METODE DAN DATA}

Penelitian ini menggunakan metode kualitatif untuk mengeksplorasi dan mendeskripsikan objek penelitian yang berupa penyertaan modal negara pada program pembangunan infrastruktur listrik desa di provinsi Bali. Dalam menganalisis data, penelitian ini menggunakan software Atlas.ti untuk melakukan kodifikasi dari kalimat atau paragraf yang relevan dan dibutuhkan untuk menjawab pertanyaan penelitian. Aplikasi ini juga membantu mengorganisasi kumpulan kode tersebut ke dalam bagan network sehingga mempermudah dalam menentukan susunan tema dalam pembahasan hasil penelitian.

Teknik pengumpulan data dilakukan melalui studi literatur dan wawancara. Studi literatur merupakan teknik yang digunakan untuk menemukan pendapat tertulis sebagai dasar penulisan yang dilakukan dengan cara mempelajari berbagai literatur terkait. Studi literatur dilaksanakan untuk mengurangi risiko terjadinya pembahasan ulang atau duplikasi terhadap literasi penelitian yang sebelumnya. Sumber literatur berupa dokumen rencana kerja BUMN terkait, peraturan perundang-undangan dan literatur berupa karya tulis ilmiah atau jurnal penelitian yang telah ada sebelumnya.

Teknik pengumpulan data lainnya adalah wawancara dengan beberapa narasumber 


\section{3 | Bina Ekonomi}

sebagai responden untuk mendapatkan informasi secara langsung. Dalam penelitian ini, wawancara dilakukan dengan mengajukan beberapa pertanyaan terstruktur berdasarkan pedoman wawancara yang tersusun secara sistematis demi memperoleh data yang dicari. Wawancara dilakukan kepada beberapa partisipan atau responden yang memiliki kaitan dengan program pengembangan listrik desa provinsi Bali.

Hasil wawancara yang dilakukan terhadap responden, kemudian dikonversi ke dalam bentuk transkrip. Selanjutnya dengan bantuan aplikasi Atlas.ti diolah untuk menemukan kodekode berupa kata yang paling relevan dan kemudian kode tersebut disusun ke dalam bagan network untuk menentukan pola atau susunan dalam membahas hasil penelitian tersebut.

\section{PEMBAHASAN}

\subsection{Pelaksanaan Investasi Pemerintah melalui PMN pada PT. PLN Distribusi Bali}

Penyertaan Modal Negara kepada PT. PLN yang telah dimulai sejak tahun 1994. Dana PMN yang diberikan dapat digunakan untuk menambah modal perusahaan yang dapat berupa aset, mesin, dan juga modal-modal lainnya (Kali, 2012). Pemberian PMN juga dapat pergunakan untuk program khusus yang menjadi prioritas pembangunan nasional. Dalam rangka hal tersebut maka Investasi Pemerintah dalam bentuk PMN pada PT. PLN digunakan untuk pengembangan program listrik desa.

Secara tidak langsung program listrik desa dapat meningkatkan taraf hidup masyarakat di pedesaan. Kondisi karakteristik, dan juga lokasi daerah pedesaan membuat timbul rasa kewajiban berbagai pihak untuk turut campur berpartisipasi pada program pembangunan listrik desa. Lembaga yang ditunjuk secara langsung untuk menjalankan program ini tidak lain adalah PT PLN (Kali, 2012). Berdasarkan Rencana Usaha Penyediaan Tenaga Listrik (RUPTL) PT PLN Tahun 2018-2027, pembangunan listrik desa merupakan program pemerintah dalam upaya memberikan fasilitas listrik kepada masyarakat pedesaan yang pendanaannya diperoleh dari Penyertaan Modal Negara (PMN) dan ditambahkan dengan Alokasi Pinjaman Lur Negeri (APLN).

Pemerintah dan PT PLN berupaya untuk mencapai rasio elektrifikasi desa berlistrik 100\%. Pembangunan listrik desa ini memperhatikan beberapa hal sebagai berikut:

1. Memberikan fasilitas listrik terhadap desa lama yang terdapat dusun belum berlistrik dan juga desa baru yang belum berlistrik;

2. Memperluas jaringan distribusi dari sistem listrik yang ada (existing) yang berdekatan disertai dengan penambahan kapasitas pembangkit listrik;

3. Pengembangan pembangkit yang menggunakan tenaga BBM untuk pedesaan yang lebih berkembang namun tidak dimungkinkan dilakukan penyambungan dari ekspansi grid sistem terdekat untuk saat ini dan juga pembangkit Energi Baru Terbarukan (EBT) belum memungkinkan dalam waktu dekat.

Untuk mencapai target tersebut, PT. PLN kemudian menggunakan tolok ukur rasio elektrifikasi sebagai dasar penentuan besaran PMN yang dialokasikan kepada Kantor PLN regional. Apabila rasio elektrifikasi tersebut kurang, maka akan diberikan prioritas dana PMN guna mendukung pemenuhan target rasio elektrifikasi di wilayah tersebut. PT PLN Unit Distribusi Bali tahun 2020 mendapatkan PMN sebesar Rp9 miliar yang selanjutnya digunakan untuk memenuhi program elektrifikasi di pedesaan Bali yang belum terdistribusi listrik. Selain itu program elektrifikasi desa tersebut juga bertujuan untuk meningkatkan pelanggan listrik dari segment rumah tangga di beberapa desa. 
Apabila dilihat secara runtut waktu, pelaksanaan PMN dalam rangka elektrifikasi desa di Bali sudah berjalan sejak tahun 2010. Tahun 2011-2018 tercatat kenaikan pelanggan listrik rumah tangga desa dengan kisaran 1.800 - 6.000 rumah tangga. Kenaikan ini juga mencakup jumlah desa yang dialiri listrik. Seiring berjalannya waktu, alokasi PMN tahun 2019-2020 yang diberikan kepada PT PLN Unit Distribusi Bali menunjukkan jumlah PMN yang lebih kecil dari tahun-tahun sebelumnya. Hal ini dikarenakan jumlah rumah tangga desa yang menjadi pelanggan sudah mencapai target $100 \%$ dari keseluruhan penduduk Bali. Capaian ini tentu saja menggembirakan karena program prioritas pemerintah melalui elektrifikasi di Bali dapat dicapai dengan baik.

Tabel 1. Alokasi PMN pada PT PLN Unit Distribusi Bali

\begin{tabular}{|c|c|c|c|c|}
\hline \multirow{3}{*}{ TAHUN } & \multicolumn{4}{|c|}{ REALISASI } \\
\hline & \multirow[b]{2}{*}{ PELANGGAN } & \multicolumn{2}{|c|}{ JUMLAH DESA } & \multirow[b]{2}{*}{ RUPIAH } \\
\hline & & BARU & LAMA & \\
\hline 2010 & 651 & - & 33 & 5.908 .306 .000 \\
\hline 2011 & 2.157 & - & 100 & $\begin{array}{c}58.796 .865 .00 \\
0\end{array}$ \\
\hline 2012 & 1.845 & - & 57 & $\begin{array}{c}51.689 .688 .65 \\
0\end{array}$ \\
\hline 2013 & 2.933 & - & 125 & $\begin{array}{c}83.538 .906 .67 \\
8\end{array}$ \\
\hline 2014 & 2.345 & - & 83 & $\begin{array}{c}40.817 .474 .61 \\
3\end{array}$ \\
\hline 2015 & 6.268 & - & 190 & $\begin{array}{c}90.780 .694 .40 \\
0\end{array}$ \\
\hline 2016 & 2.568 & - & 94 & $\begin{array}{c}56.344 .036 .56 \\
9\end{array}$ \\
\hline 2017 & 2.322 & - & 120 & $\begin{array}{c}57.720 .380 .00 \\
0\end{array}$ \\
\hline 2018 & 2.643 & - & 108 & $\begin{array}{c}65.894 .027 .84 \\
9\end{array}$ \\
\hline 2019 & 277 & - & 41 & 5.496 .367 .655 \\
\hline 2020 & 354 & - & 27 & 9.921 .684 .365 \\
\hline & 24.363 & - & 978 & $\begin{array}{l}526.908 .431 .7 \\
79\end{array}$ \\
\hline
\end{tabular}

Sumber :diolah dari laporan realisasi PMN 2010-2020

Sebagai pendalaman atas pemanfaatan PMN, penelitian ini mengumpulkan data melalui wawancara kepada responden yang melakukan atau membidangi pelaksanaan pembangunan transmisi dan GI di PT. PLN Unit Distribusi Bali. Berdasarkan Networks knowledge yang dikembangkan dari hasil analisis wawancara terhadap narasumber menggunakan Atlas.ti, diperoleh relasi antar kode yang menjelaskan beberapa hal sebagai berikut:

a. Tujuan PMN di PT PLN Unit Distribusi Bali

Investasi Pemerintah dalam bentuk Penyertaan Modal Negara bertujuan untuk pengembangan program listrik desa. Kaitannya dengan program listrik masuk desa adalah karena PMN untuk tiap wilayah tidaklah besar, maka jika untuk pembangunan pembangkit dan gardu induk tidak menggunakan dana yang berasal dari PMN, melainkan dengan Loan ADB atau pinjaman. 


\section{5 | Bina Ekonomi}

b. Pelaksanaan PMN di PT PLN Unit Distribusi Bali

Berdasarkan wawancara yang dilakukan, pelaksanaan PMN pada PT PLN Unit Distribusi Bali dinilai telah berjalan dengan baik. Hal tersebut terbukti dengan tercapainya target rasio elektrifikasi 100\% di Bali pada tahun 2018 dan didaftarkan ke Museum Rekor Indonesia (MURI) pada tahun 2019 sehingga dapat menjadi bukti nyata bahwa Penyaluran dan Implementasi penggunaan dana PMN telah berjalan dengan baik, sesuai dengan Rencana Kerja Pemerintah (RKP) yang diusulkan dan tidak terdapat keterlambatan.

c. Pembangunan Listrik Desa di PT PLN Unit Distribusi Bali

Berdasarkan Peraturan Menteri ESDM Nomor 38 tahun 2016 tentang Percepatan Elektrifikasi di Pedesaan Belum Berkembang, Terpencil, Perbatasan dan Pulau Kecil Berpenduduk Melalui Pelaksanaan Usaha Penyediaan Tenaga Listrik Skala Kecil. Salah satu Program Pemerintah untuk memenuhi rasio elektrifikasi di daerah - daerah ini adalah Program Listrik Desa. Maka, PLN Regional yang rasio elektrifikasinya belum memenuhi target, dana PMN yang diterimanya akan digunakan untuk memenuhi Program Pemerintah tersebut. Upaya memenuhi Rasio Elektrifikasi $100 \%$ tersebut tidaklah mudah, karena terdapat beberapa kendala yang menghambat tercapainya target tersebut. Kendala yang dimaksud adalah kendala medan yang berat dan juga pembukaan jalan yang semulanya pepohonan hingga dapat di akses menuju pemukiman warga di pedesaan. Dari kendala tersebut sangat mungkin terjadi pembengkakan biaya karena harus menyewa alat berat lebih banyak dan juga biaya lainnya yang berkaitan. Namun demikian tim PLN Unit Distribusi Bali dibantu oleh masyarakat pedesaan pedalaman bergotong - royong dengan antusias untuk mendapatkan fasilitas listrik untuk desa mereka.

\section{d. Monitoring dan Evaluasi}

PT PLN Unit Distribusi Bali melakukan monitoring dan evaluasi dengan menyiapkan penyusunan Standar Operasional Prosedur pada tahun berikutnya berdasarkan kinerja proyek listrik desa tahun sebelumnya. Saat ini PT PLN UID Bali juga sudah menggunakan RKP berbasis risiko yang dimulai dari tahun 2019 dan tahun 2020, sehingga alur proses perencanaan sampai eksekusi sudah menggunakan kajian risiko beserta mitigasi risiko tersebut. Realisasi penggunaan PMN dimuat dalam laporan khusus yang dilaporkan ke PLN regional Jawa - Bali dan kemudian dilaporkan kepada Kantor pusat PT. PLN dan pemerintah. PLN UID Bali melakukan rapat untuk membuat SOP dimana SOP tersebut disusun berdasarkan pelaksanaan listrik desa tahun sebelumnya. Monitoring dan Evaluasi dalam tahun anggaran berjalan dilakukan dengan melihat progress realisasi setiap dua minggu sekali untuk menguraikan proses sehingga bisa dilihat dari progress jika ada kendala, dan keterlambatan selanjutnya disampaikan dalam rapat kerja. Sehingga tidak ada lagi daerah-daerah yang terkendala program listrik desa yang didanai dari PMN. 


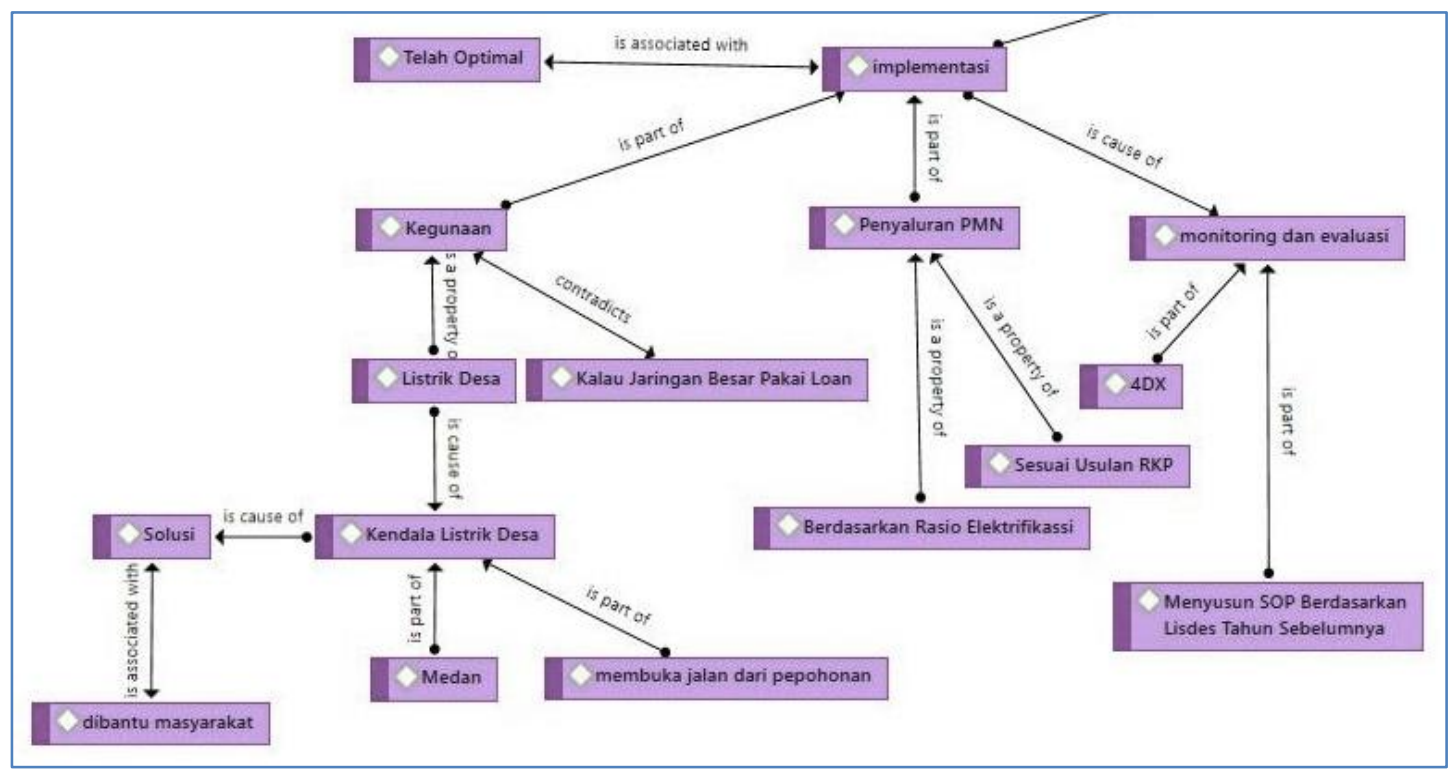

Gambar 1 : Network view yang diolah melalui aplikasi Atlas.ti

Secara umum penggunaan investasi pemerintah dalam bentuk PMN yang dilakukan PT. PLN dengan tujuan meningkatkan rasio elektrifikasi di daerah prioritas terbilang cukup sukses. Hal tersebut dapat dilihat dari rasio elektrifikasi yang terus meningkat seiring berjalannya waktu. Berdasarkan data yang disampaikan dalam lokadata 2014, Rasio elektrifikasi Indonesia keseluruhan dari tahun 2014 - 2020 telah meningkat sebanyak 14,85\% dari 84,35\% pada 2014 menjadi 99,2\% pada tahun 2020.

Rasio elektrifikasi di Indonesia tahun 2014-2020, khususnya untuk daerah Jawa dan Bali telah meningkat drastis. Provinsi Jawa Barat, Jawa Tengah, dan Jawa Timur masing-masing telah meningkat sebesar 12,96 \%, 10,96 \% , dan 14,45 \%. Khusus Provinsi Bali, tahun 2019 mengalami peningkatan rasio elektrifikasi sebesar $14,83 \%$ sekaligus menjadi capaian akhir rasio elektrifikasi $100 \%$. Hal ini menjadi prestasi karena sebagai provinsi pertama yang mampu mencapai rasio Elektrifikasi Penuh $100 \%$.

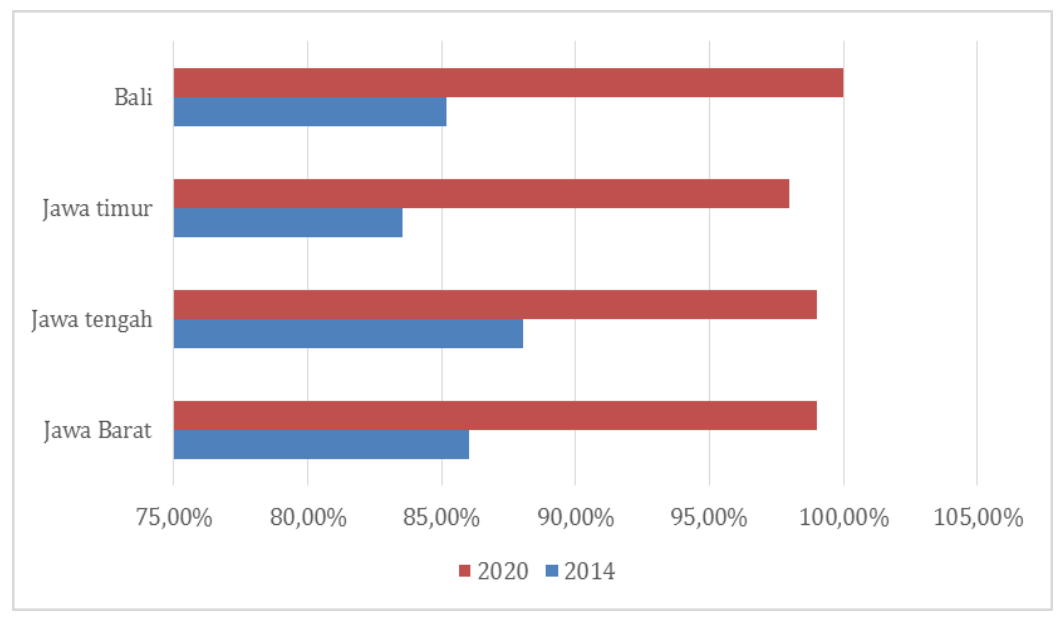

Gambar 2 : Rasio Elektrifikasi Wilayah Jawa - Bali 2014 -2020

Sumber: diolah dari databoks.katadata dan lokadata

\subsection{Manfaat Investasi Pemerintah Melalui PMN pada PT PLN Distribusi Bali}

Berdasarkan pada Peraturan Pemerintah Republik Indonesia Nomor 1 Tahun 2008 Tentang Investasi Pemerintah, Pada Pasal 1 ayat 1 dijelaskan bahwa Investasi Pemerintah merupakan 


\section{7 | Bina Ekonomi}

penempatan sejumlah dana dan/atau barang dalam jangka panjang dengan tujuan demi memperoleh manfaat ekonomi, sosial, dan / atau manfaat lainnya. Kemudian pada Pasal 2 Ayat 1, disampaikan bahwa Investasi Pemerintah dimaksudkan untuk memperoleh manfaat ekonomi, sosial, dan/atau manfaat lainnya.

Pengukuran manfaat PMN berfokus pada manfaat ekonomi dan sosial. Manfaat ekonomi dari investasi pemerintah melalui Penyertaan Modal Negara dapat berupa keuntungan finansial bagi perusahaan ataupun keuntungan berupa dividen yang diterima oleh negara. Manfaat ekonomi pada dasarnya dapat diukur dengan metode CBA atau Cost and Benefit Analysis. Manfaat sosial cenderung lebih sulit untuk diukur karena manfaat sosial tidak memiliki variabel baru seperti manfaat ekonomi yang dapat terlihat jelas variabel nya dengan jelas. Sehingga, dalam pengukuran manfaat sosial maka akan dilakukan dengan data kualitatif yang ditujukan untuk mencari hubungan tidak langsung antara pembangunan yang didanai oleh PMN terhadap fenomena /manfaat yang diterima masyarakat, misalnya dengan menambahnya produktivitas masyarakat, mengurangi angka pengangguran dan lainnya.

Pada dasarnya, yang dimaksud dengan manfaat ekonomi, sosial, dan/atau manfaat lainnya pada Peraturan Pemerintah Republik Indonesia Nomor 1 Tahun 2008 Tentang Investasi Pemerintah adalah :

a. Keuntungan berupa dividen, bunga, dan pertumbuhan nilai perusahaan yang mendapatkan Investasi Pemerintah sejumlah tertentu dalam jangka waktu tertentu;

b. Peningkatan berupa jasa dan keuntungan bagi hasil investasi sejumlah tertentu dalam jangka waktu tertentu;

c. Peningkatan pemasukan pajak bagi negara sejumlah tertentu dalam jangka waktu tertentu sebagai akibat langsung dari investasi bersangkutan; dan/atau

d. Peningkatan penyerapan tenaga kerja sejumlah tertentu dalam jangka waktu tertentu sebagai akibat langsung dari investasi bersangkutan.

\subsubsection{Pengukuran Manfaat Ekonomi}

Manfaat ekonomi merupakan salah satu manfaat yang bersifat tangible atau berwujud. Manfaat ini dapat dilihat dari bagaimana peningkatan income bagi PT PLN khususnya PLN UID Bali, dan juga bagaimana investasi ini memberi income dalam bentuk dividen bagi pemerintah sebagai pemilik modal. Dalam mengidentifikasi manfaat ekonomi dapat menggunakan impact analysis yang merupakan satu metode pendekatan untuk mengidentifikasi manfaat berwujud yang muncul akibat adanya investasi pada pembangunan listrik desa. Pendekatan ini terkait dengan realisasi peningkatan income yang diperoleh dengan adanya pembangunan tersebut.

Tabel 2. Perbandingan Total Cost, Income, dan dividen tahun 2013 dan 2017

\begin{tabular}{|l|r|r|r|}
\hline $\begin{array}{c}\text { Jenis Biaya/ } \\
\text { Income/ Dividen }\end{array}$ & 2013 & $\begin{array}{c}\text { Peningkatan } \\
\text { selama } \\
\mathbf{2 0 1 4 - 2 0 1 6}\end{array}$ & 2017 \\
\hline $\begin{array}{l}\text { Total cost Listrik } \\
\text { Desa (PMN + }\end{array}$ & $\mathbf{8 7 . 3 2 4 . 4 8 2 . 2 3}$ & & \\
APLN) & $\mathbf{7}$ & & $\mathbf{4 3 . 0 6 2 . 1 9 5}$ \\
\hline $\begin{array}{l}\text { Penambahan KK } \\
\text { teraliri listrik di }\end{array}$ & 2.933 & 11.181 & 2.322 \\
\hline
\end{tabular}




\begin{tabular}{|c|c|c|}
\hline \multicolumn{3}{|l|}{$\begin{array}{l}\text { wilayah regional } \\
\text { Jawa-Bali }\end{array}$} \\
\hline Dividen & (kerugian & Rp663.451.273.576 * \\
\hline pemerintah dari & operasional & $7 \%=$ \\
\hline PLN UID Bali* & tahun 2013) & Rp46.441.589.150 \\
\hline dividen & (kerugian & \\
\hline pemerintah total & operasional & \\
\hline oleh PLN Pusat* & tahun 2013) & 27,69 miliar \\
\hline
\end{tabular}

Sumber: Diolah dari ARPLN 2014 dan 2017, Lapkeu 2013 dan 2017 PLN UID Bali

Manfaat ekonomi dari program listrik desa yang dibiayai melalui PMN ditambah dengan dana dari PLN dapat dilihat proyeksinya dari data yang tersaji pada tabel 2. Pada tahun 2013 kebutuhan biaya untuk pembangunan program listrik desa mencapai Rp 87.324.482.237 yang menghasilkan penambahan rumah tangga (RT) teraliri listrik sebanyak 2.933 RT. Selama kurun waktu 2014-2016 terdapat penambahan RT teraliri listrik sebanyak 11.181 RT. Tahun 2017 juga terjadi penambahan RT teraliri listrik sebanyak 2.322 RT dengan nilai biaya investasi listrik desa sebesar Rp 43.062.195.

Dari sisi pertumbuhan pelanggan RT, penambahan coverage pada tahun 2013 sebesar 2933 pelanggan masih relatif kecil jika dibandingkan dengan modal biaya yang dikeluarkan pada tahun berjalan. Hal ini berbeda dengan tahun 2017 dimana peningkatan pelanggan sebesar 2322 pelanggan dengan modal yang jauh lebih sedikit. Hal ini dapat terjadi karena Investasi dari Pemerintah yang kemudian dilaksanakan oleh PT PLN dalam hal ini Pembangunan berdasarkan Program Listrik desa bertujuan untuk pemenuhan program prioritas nasional dan keuntungannya merupakan jangka panjang.

Dari segi manfaat ekonomi berupa pendapatan dividen, pada tahun 2013, pemerintah pusat tidak mendapatkan dividen dari PT PLN dikarenakan tidak adanya penerimaan bersih (net revenue) yang diterima di tahun tersebut, baik dari PT PLN Regional Jawa-Bali Unit Distribusi Bali ataupun PT PLN Pusat. Pada tahun 2017 PT. PLN berhasil membukukan keuntungan dimana dividen yang disetorkan PT PLN kepada pemerintah lebih tinggi dari biaya investasi pemerintah yang diberikan untuk menjalankan proyek program pembangunan Listrik Desa pada tahun berjalan. Dividen yang diberikan PT PLN Pusat kepada pemerintah adalah sebesar 27,69 Miliar Rupiah dimana Rp46.441.589.150 dividen tersebut berasal dari 7\% Laba Operasional PT PLN Regional Jawa-Bali Unit Distribusi Bali.

Pembangunan listrik desa pada tahun 2013 tidak secara langsung menghasilkan manfaat ekonomi berupa dividen karena di tahun tersebut rasio elektrifikasi belum setinggi pada tahun 2017 dan juga PT PLN sedang gencar melakukan di tahun 2013 tersebut. Dalam ARPLN 2014 disebutkan pada tahun 2013 PT PLN mengalami kerugian operasional secara menyeluruh sehingga menyebabkan tidak adanya dividen yang dibagikan kepada pemerintah. Income berupa dividen di dapat dari laba bersih operasional yang berasal dari penerimaan pembayaran dari pelanggan, sehingga dalam kasus PT PLN khususnya Regional Jawa-Bali Unit Distribusi Bali, tahun 2013 merupakan tahun pembangunan jaringan infrastruktur utama seperti jaringan atas bertegangan tinggi, dadu utama, dan lainnya sehingga belum mampu menambah pelanggan dalam jumlah besar.

Di sisi lain, tahun 2017 dapat dikatakan tahun penyempurnaan pembangunan menuju rasio elektrifikasi $100 \%$ untuk wilayah Bali yang akhirnya terwujud tahun 2018, sehingga tahun 2017 jaringan utama sudah tersedia secara menyeluruh dan hanya 
diperlukan membuat jaringan pendukung (dari jaringan utama menuju ke rumah-rumah pelanggan) maka dana yang diperlukan relatif jauh lebih kecil, namun terlihat mampu menambah pelanggan dengan jumlah signifikan.

Jika dilihat dari beberapa penjelasan tersebut, maka dapat dilihat bahwa manfaat ekonomi atas investasi pemerintah melalui PMN pada PT. PLN Unit DIstribusi Bali tidak diterima secara langsung saat program listrik desa mulai berjalan. Manfaat ekonomi baru diterima pemerintah pusat pada kurun waktu beberapa tahun berikutnya. Meskipun dari tahun 2013-2017 jumlah dividen yang diterima pemerintah lebih kecil dari total biaya yang dikeluarkan melalui PMN. Penelitian ini menghasilkan argumentasi bahwa manfaat ekonomi atas PMN yang tidak dirasakan dalam jangka pendek bukan merupakan inefisiensi dari investasi pemerintah, melainkan 'late effect' atau efek yang terlambat daripada investasi jangka panjang yang diterapkan. Laba operasional yang akhirnya menjadi dividen di tahun 2017 membuktikan bahwa hasil investasi dalam bentuk dividen merupakan akumulasi keuntungan investasi dari beberapa tahun sebelumnya.

Terlepas dari perhitungan finansial dari sudut pandang PT PLN selaku pelaksana investasi dan pemerintah pusat selaku pemberi modal, masyarakat desa sebagai sasaran dari program listrik desa ini merasakan manfaat ekonomi secara langsung dan tidak langsung (efek ekonomi berganda) dari penggunaan listrik desa untuk kegiatan ekonomi di desa yang dialiri listrik. Tentunya ada peningkatan produktivitas setelah teraliri listrik dibandingkan sebelum teraliri listrik.

Sebagai contoh, penghitungan manfaat ekonomi yang dirasakan masyarakat yang sebelumnya tidak merasakan listrik adalah membandingkan biaya yang dikeluarkan rumah tangga dalam memelihara lampu sebagai alat penerangan di rumah. Dari perbandingan pada tabel 3 terlihat adanya pengurangan biaya yang signifikan yang dirasakan masyarakat dalam hal penerangan di malam hari. Sebelum mendapat aliran listrik masyarakat mengeluarkan biaya sekitar Rp 100.000 untuk penerangan. Namun setelah adanya listrik, masyarakat hanya perlu mengeluarkan biaya 5\% nya saja yaitu 5 ribu rupiah per bulannya dan mendapatkan lampu 10 Watt untuk menerangi ruangan. Belum lagi dampak lingkungan, dimana tersedianya listrik tidak menimbulkan polusi yang dapat mengganggu kesehatan apabila dibandingkan dengan penggunaan lampu minyak tanah.

Tabel 3. Perbandingan Biaya Penerangan menggunakan Lampu Minyak Tanah dengan Lampu LED 10 watt

\begin{tabular}{|c|c|c|c|}
\hline Jenis lampu & Biaya & Jangka waktu & $\begin{array}{c}\text { Biaya Dalam } 1 \\
\text { bulan }\end{array}$ \\
\hline $\begin{array}{l}\text { Lampu Minyak } \\
\text { tanah }\end{array}$ & Rp 14.000 / liter & $\begin{array}{l}\text { Bertahan rata- } \\
\text { rata hingga } 4 \text { hari } \\
\text { pemakaian } \\
\text { hanya di malam } \\
\text { hari }\end{array}$ & $\begin{array}{l}30 / 4^{*} 14000 \\
=\operatorname{Rp} 105.000\end{array}$ \\
\hline $\begin{array}{l}\text { Lampu Listrik } \\
\text { LED 10W }\end{array}$ & $\begin{array}{l}10 \mathrm{~W}^{*} 12 \text { jam (gelap) } \\
= \\
0.12 \mathrm{Kwh}^{*} 1400 / \mathrm{kw} \\
\mathrm{h}\end{array}$ & Rp 168 Per hari & $\begin{array}{l}\operatorname{Rp} 168 * 30 \text { hari } \\
=\operatorname{Rp} 5.040\end{array}$ \\
\hline
\end{tabular}

Sumber: diolah dari data hasil wawancara dengan narasumber 


\subsubsection{Pengukuran Manfaat Sosial}

Manfaat sosial merupakan salah satu manfaat yang bersifat intangible atau tak berwujud. Pengukuran manfaat sosial ini dapat dikatakan lebih rumit dari pada manfaat ekonomi, manfaat ekonomi dapat diukur dengan variabel yang tepat dan angka yang pasti sedangkan manfaat sosial banyak dipengaruhi variabel lain, keadaan sosial di wilayah sekitar, kondisi masyarakat dan lainnya, sehingga tidak bisa digeneralisir.

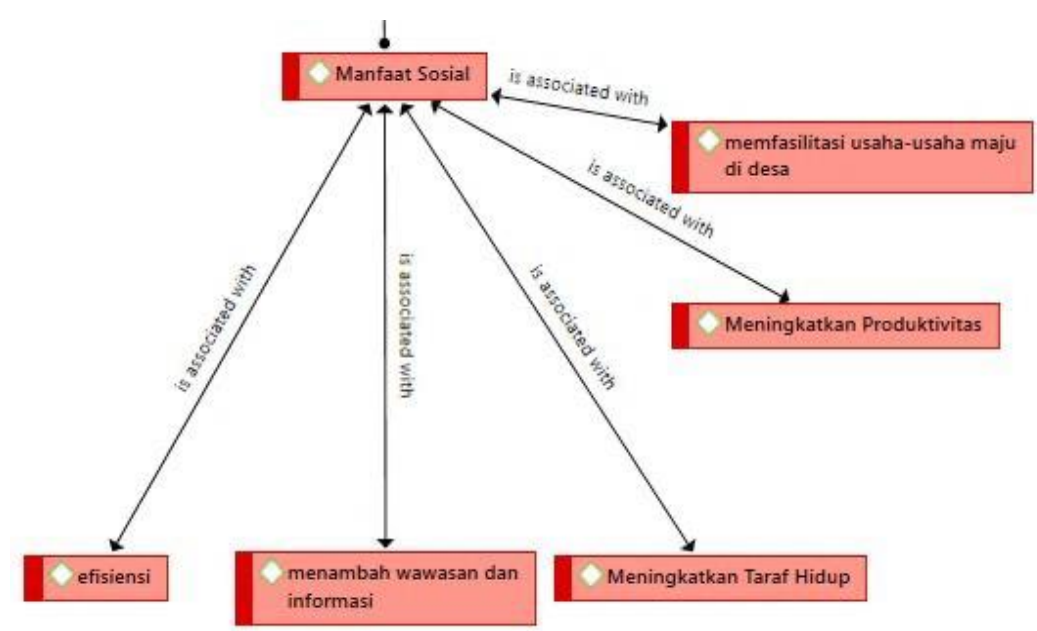

Gambar 3 : Network Diagram Manfaat Sosial

Berdasarkan Networks knowledge yang dikembangkan dari hasil analisis wawancara terhadap narasumber menggunakan Atlas.ti, diperoleh relasi antar kode yang di analisis terkait dengan manfaat sosial. Dari pernyataan narasumber yang bekerja pada PT PLN UID Bali, Investasi Pemerintah dalam bentuk Penyertaan Modal Negara dapat memberikan berbagai manfaat sosial seperti yang ditargetkan pemerintah dalam mengadakan program listrik desa ini, manfaat sosial tersebut antara lain dapat melistriki masyarakat yang memang berada di daerah terpencil , kalau finansial, jika dibandingkan dengan investasinya, PLN tidak mendapat dan juga tidak mencari keuntungan.

Pada masyarakat desa khususnya, dengan memiliki listrik dapat meningkatkan taraf hidup. Sebagai proyeksi, rupiah per KWH tarif listrik untuk 1 bohlam dalam 8 jam, dia hanya akan menghabiskan sangat sedikit rupiah, yang jika 1 bulan paling hanya 15 ribu untuk 1 bohlam, kalau dia menggunakan lampu minyak tanah, 19 ribu minyak tanah 1 liter missal hanya untuk 4 hari, belum lagi asap yang dihasilkan dan berbahaya. Meningkatkan produktivitas juga, misalnya untuk membuat kerajinan tangan, kebutuhan upacara sampai larut / lembur, memfasilitasi usaha-usaha maju di desa, seperti pengrajin kayu di desa dengan alat" modern dan lebih efektif, alat giling listrik, pemanas listrik, dan banyak lagi yang nantinya dapat membuka lapangan kerja baru. Juga menambah wawasan dan informasi, sesuai dengan tagline PLN dulu, yaitu listrik untuk kehidupan yang lebih baik.

\section{SIMPULAN}

Berdasarkan pembahasan terkait Penyertaan Modal Negara pada program Pembangunan Listrik Desa di Provinsi Bali dapat disimpulkan beberapa hal sebagai berikut :

1. Pelaksanaan investasi pemerintah melalui Penyertaan Modal Negara pada PT. PLN Region Jawa - Bali Unit Distribusi Bali berjalan dengan optimal. Hal tersebut terlihat dari keberhasilan pemenuhan target rasio elektrifikasi $100 \%$ di provinsi Bali sesuai dengan 


\section{1 | Bina Ekonomi}

Rencana Usaha Penyediaan Tenaga Listrik (RUPTL) PT PLN Tahun 2018-2027. Tidak hanya memenuhi target, kinerja PT PLN Region Jawa - Bali Unit Distribusi Bali memperoleh rekor MURI pada tahun 2019 sebagai provinsi pertama yang mencapai rasio elektrifikasi $100 \%$.

2. Pencapaian kinerja tersebut dilakukan melalui program pembangunan listrik desa di Provinsi Jawa Bali. Program ini bertujuan untuk membantu mendapatkan fasilitas listrik pada rumah warga yang berada di pedesaan yang mengalami kesulitan akses listrik. Beberapa tantangan dan kendala terutama medan yang berat dan juga akses jalan yang belum tersedia untuk kendaraan. Meskipun demikian masyarakat desa antusias bergotong-royong menyukseskan program listrik desa.

3. Manfaat dari investasi pemerintah melalui PMN pada PT PLN Region Jawa - Bali Unit Distribusi Bali dibagi menjadi manfaat ekonomi dan manfaat sosial :

a. Manfaat Ekonomi menunjukkan hasil bahwa manfaat ekonomi berupa dividen yang yang diperoleh pemerintah pusat baru dihasilkan 6 tahun sejak projek pembangunan listrik desa dilaksanakan pada tahun 2011. Disisi lain, masyarakat yang sebelumnya tidak merasakan listrik, dengan adanya listrik desa merasakan manfaat dari segi ekonomi, jika dibandingkan dengan sebelum dialiri listrik. Contoh manfaat ekonomi tersebut adalah berkurangnya biaya operasional RT dalam membiayai penerangan di malam hari.

b. Manfaat Sosial dari PMN pada PT PLN Region Jawa - Bali Unit Distribusi Bali terbagi menjadi manfaat sosial langsung dan tidak langsung. Manfaat langsung yaitu seperti meningkatkan produktivitas, efisiensi biaya dan tenaga, meningkatkan taraf hidup, menambah wawasan dan informasi, dan juga memfasilitasi usaha-usaha maju di desa. Manfaat tidak langsung adalah impact dari terjangkaunya listrik di seluruh kalangan masyarakat, antara lain meningkatnya angka melek huruf, meningkatnya lapangan pekerjaan, menurunnya jumlah pengangguran, meningkatnya indeks perkembangan manusia, meningkatnya Indeks implisit Pertanian, Kehutanan, dan Perikanan; Pertambangan dan Penggalian; Industri Pengolahan; Pengadaan Listrik dan Gas; Pengadaan Air; Pengelolaan Sampah, Limbah dan Daur Ulang; serta Konstruksi. 


\section{DAFTAR PUSTAKA}

Afifi, A. A., \& Sastry, S. V. S. (2013). Tahapan Rasio Elektrifikasi 100\%. Journal of Chemical Information and Modeling, 53(9).

Aziz, A. (2007). Ekonometrika Teori \& Praktik Eksperimen dengan MATLAB. Universitas UIN Malang.

BAKROH, D. S. B. (2020). PENGELOLAAN INVESTASI PEMERINTAH. Politeknik Keuangan Negara STAN.

Ekawati, R. K. (2016). Teknik Mengukur Manfaat tangible dan intangible.

Kali, A. (2012). Analisis Program Listrik Pedesaan Dalam Meningkatkan. MektekMektek, 14.

Lokadata. (2014). Rasio elektrifikasi berdasarkan provinsi Tahun 2014. Beritagar. https://lokadata.beritagar.id/chart/preview/rasio-elektrifikasi-berdasarkan-provinsi1482476963\#: :text=Rasio elektrifikasi nasional sampai dengan,2014 mencapai $84 \% 2 \mathrm{C} 35 \% 25$.

PT PLN. (2018). RUPTL PLN 2018-2027.

Riastuti, A. K. (2008). Analisis Faktor-Faktor Yang Mempengaruhi Investasi Pemerintah Di Bidang Infrastruktur Listrik Di Indonesia Tahun 1986-2006 (Doctoral dissertation, Universitas Airlangga).

Setjen DPR RI, B. A. A. dan P. A. (2016). Penyertaan Modal Negara kepada BUMN. Buku 1 Rancangan Undang-Undang Tentang Anggaran Dan Belanja Negara Tahun 2016, 1-4. http://www.dpr.go.id/doksetjen/dokumen/biro-apbn-apbn-Penyertaan-Modal-Negarapada-BUMN-1441158796.pdf

Sulistiani, H., Miswanto, M., Alita, D., \& Dellia, P. (2020). Pemanfaatan Analisis Biaya Dan Manfaat Dalam Perhitungan Kelayakan Investasi Teknologi Informasi. Edutic - Scientific Journal of Informatics Education, 6(2). https://doi.org/10.21107/edutic.v6i2.7220

Sumardjoko, I., \& Akhmadi, M. H. (2019). Pengembangan Infrastruktur Konektifitas Sebagai Daya Ungkit Ekonomi Dan Pemangkas Kemiskinan Jawa Timur. Jurnal Manajemen Keuangan Publik, 3(1), 22-31. 